\title{
Une nouvelle équipe à la direction du Journal de la
} société des américanistes

Le Président

\section{(2) OpenEdition}

\section{Journals}

Édition électronique

URL : https://journals.openedition.org/jsa/14208

DOI : 10.4000/jsa. 14208

ISSN : 1957-7842

\section{Éditeur}

Société des américanistes

\section{Édition imprimée}

Date de publication : 31 décembre 2015

Pagination : 7

ISSN : 0037-9174

\section{Référence électronique}

Le Président, "Une nouvelle équipe à la direction du Journal de la société des américanistes », Journal de la Société des américanistes [En ligne], 101-1 et 2 | 2015, mis en ligne le 15 mars 2016, consulté le 24 février 2023. URL : http://journals.openedition.org/jsa/14208 ; DOI : https://doi.org/10.4000/jsa.14208 


\section{Une nouvelle équipe à la direction du Journal de la société des américanistes}

Périodiquement, depuis sa création en 1896, le Journal de la société des américanistes voit une équipe de direction passer le relais à la suivante. Bienvenue à Olivier Allard et Pierre Deléage, qui ont accepté depuis le début de l'année de reprendre en tandem les fonctions de directeurs de la rédaction de la revue. Ces deux jeunes ethnologues mettent ainsi en commun leur expérience du travail scientifique au service de la communauté américaniste. En regardant l'ours de la revue décennie après décennie, on ne peut que s'émerveiller de voir les forces vives de chaque génération reprendre la tâche avec compétence et enthousiasme pour faire vivre à travers notre revue ce qui est peut-être la meilleure illustration de ce qui fait une institution : un collectif dont les membres changent au fil du temps, mais dont les valeurs et les exigences demeurent identiques.

Profitons de l'occasion pour rappeler tout ce que nous devons à l'équipe qui vient de quitter le devant de la scène tout en continuant à prêter mainforte dans les coulisses. Dominique Michelet, d'abord, qui s'est consacré au Journal de la société des américanistes pendant près d'un quart de siècle, avec la rigueur scientifique, la détermination sans faille, l'immense érudition et le sens des responsabilités collectives qu'on lui connaît. On lui saura gré d'avoir fait vivre la revue dans des circonstances qui ne furent pas toujours faciles, en raison notamment du désengagement partiel des autorités de tutelle. Alain Breton l'a accompagné comme rédacteur adjoint depuis 2002, mais en réalité depuis bien plus longtemps car notre collègue dont on sait le goût qu'il a pour la belle ouvrage en matière d'édition joue un rôle central dans la revue depuis des années. On peut en dire autant d'Isabelle Daillant dont l'esprit analytique incisif et le respect qu'elle éprouve pour l'expression juste, quelle que soit la langue, n'ont cessé de faire merveille. Qu'ils soient tout trois chaleureusement remerciés pour leur dévouement et pour le labeur accompli au service commun de notre passion : la recherche scientifique sur les Amériques.

Le Président 